\title{
ANALYSIS OF APPLYING ZOOM CLOUD MEETING TOWARDS EFL LEARNING IN PANDEMIC ERA COVID-19
}

\author{
Agus Rahmat ${ }^{1}$ \\ STMIK Handayani Makassar \\ rahmatppsunm14@gmail.com \\ Nurul Fachrunnisa ${ }^{2}$ \\ Universitas Muslim Maros \\ nurulfachrunnisa@umma.ac.id
}

\begin{abstract}
The objectives of this research are to find out the students' perspective, the barriers, the advantages and disadvantages as well as the strategies of applying Zoom Cloud Meeting app towards EFL learning in pandemic era Covid-19. The subjects of this research are five students of Manajemen Informatika (MI) and five students of Technical Information Extensive (TI Ext). The research employed descriptive qualitative design by using selfreport questionnaire and interview as the research instruments. The result of research showed that (1) the existence of zoom cloud meeting in EFL learning is very effective to stop the spreading of covid 19 in pandemic era but the learning process cannot be perfect than the conventional learning (2) the main barriers of applying zoom cloud meeting are the bad network and the usage of big internet quota. (3) The advantages are many kinds of good features and high quality access, more flexible, comfortable, and relaxed and disadvantages are the learning condition cannot be felt, the learning is not perfect, make the students lazier and less of togetherness (4) the effective strategies are the methods must be interactive and the materials have to be delivered directly with audio and visual.
\end{abstract}

Keywords: Analysis; Zoom; Learning; Pandemic; Covid-19

\section{INTRODUCTION}

More than a hundred countries over the world contaminated by a virus namely Covid-19 (Corona Virus Disease 2019). The spreading of this virus occurs very rapidly in the society especially the people who are more than 60 years old because the immunity of the people like this are already decreased. "Corona virus disease 2019 (COVID-19) originating from Hubei Province of the People's Republic of China has become a current pandemic over the world. Many countries have been affected by this virus. In late January 2020, a global health emergency state was announced by the (WHO, 2020) Emergency Committee as COVID-19 confirmed cases have been increasing internationally. COVID-19 has spread in all continents, but Antarctica as of 26 February 2020. Latest news on COVID-19 has overloaded worldwide mass media every day in 2020. The World 
Health Organization (WHO) has recently declared COVID-19 a public health emergency of international concern. As of February 25, 2020, a total of 81,109 laboratory-confirmed cases had been documented globally. Covid-19 has spread rapidly until Indonesia. In 1 April 2020, the number of confirmed COVID-19 cases in Indonesia has reached more than 1.500 cases. The National Disaster Management Authority of Republic of Indonesia (BNPB) has decided to extend the period of disaster emergency caused by COVID-19 pandemic until 29 May 2020, (Atmojo \& Nugroho, 2020)."

The spread of Covid-19 has been affected over the world, therefore WHO declared that this case becomes a pandemic. Soon after the declaration, all of the countries have prepared and planned some strategies to maintain their citizen from this virus. In Indonesia itself, many sectors were affected by this virus, above all economic and education sectors. Many ways already applied by the government to maintain the education keep running as usual. Therefore, the Minister of Education and Culture of Republic of Indonesia has instructed schools to carry out online learning since 17 March 2020 for COVID-19 affected areas. Soon after that, the Minister of Education and Culture of Republic of Indonesia has ordered all education units to run online learning from 24 March 2020 due to the increasing spread of COVID-19 and maintaining the health of students, teachers, and all educational staff. According to Nadiem Makarim (the Minister of Education and Culture of Republic of Indonesia) through decree no 4 year 2020 which content about implementing education policies in the emergency phase of pandemic of corona virus. "The policies content four main points. Firstly, study at home trough daring or distance learning implement to provide learning experience without being burdened to complete the curriculum target for grade promotion or graduation. Secondly, distance learning can be focused on life skills education for example about Covid-19. Thirdly, Students activities and task could be varied among students in accordance with their interest and condition including learning gap and facilities at home. The last, proof or product activity should be given feedback which is qualitative and useful for the teachers without giving a score or quantitative grade, (Yulia, 2020)."

\section{British, Jurnal Bahasa dan Sastra Inggris}


These policies lead students to learn from home and teachers to work from home, too. It fully replaces face-to-face learning in classroom setting into online learning which possibly lasts till the end of semester due to the COVID-19 pandemic. It becomes a new challenge for both students and teachers to run online learning. The global spread of COVID-19 pandemic causes class suspensions resulting in the needs of online learning. According to Cao et al, these actions certainly give impact on education, particularly students' growth, (Atmojo \& Nugroho, 2020)." According to study done by Learning House, Inc. (2018) in (Yulia, 2020), showed that 85\% students who follow face to face and online learning felt that they have the same and some better experiences in learning for both face to face and online program. $37 \%$ felt it as superior experience.

This pandemic causes the online learning become an unprepared situation and occur in a sudden. Most of universities follow the instruction of the government to stop or minimalize the spread of Covid-19. The universities also try to search for the effective strategies to figure out this challenges in order to the quality of education can be optimal as usual and enhanced. This fully online learning also is very seldom occurs in the world, especially learning English as a foreign language (EFL) in Indonesia. English as a foreign language has a special status in Indonesia because almost schools and universities learn English in every department. Besides, by mastering English one can be easily accepted in the job position and also much appreciated in the work place, business and tourism. During Pandemic era Covid-19 has influenced many activities in daily life, especially in education. The learning and teaching process is usually conducted in the school or university, it becomes at home through some technologies connected with the internet to stop the spread of Covid-19 broader. According to Jacobs (2013), “online learning is as effective as traditional classroom learning. How much or how well a student learns is determined by the quality of the online instruction. If a course is well designed and well implemented, students will learn more than in a poorly designed course, (Jacobs, 2013)". Online learning course has a strength, challenge and obstacles itself to be applied. 
Many kinds of technologies are often applied by the teachers and the students in Indonesia but the most booming in education is Zoom Cloud Meeting. The office of this application located in San Jose, California, United State held since 2011 ago, used by some organizations and companies to accommodate their employees from the long distance. Zoom cloud meeting app is a mean of communication by using video which can be used in cellular phone, computer and so forth. Generally, the users always use this application to conduct a meeting until video and audio conference. This app becomes a choice for the businessman, employees, workers, educators and the students are forced to finish their activity or job because of pandemic Covid- 19 .

The components of this app are as follows: (1) Video and audio HD, the zoom app supported until a thousand participants and 49 videos in the screen which have high definition (HD) quality. (2) The users can be using the screen concurrently. (3) Has end to end encryption and password so that the security of this app is very safe. (4) The users can record the meeting and save its record in their equipment. (5) The users can schedule their meeting in the application. (6) The conversation can be easily to be done, while the history of the conversation can be easily searched and the files can be saved during 10 years. The users can get this application by downloading in PC and Android namely Zoom Cloud Meeting. From the official site, Zoom app has reach some appreciations such as Leader in Gartner 2019 Magic Quadrant for Meeting Solution, 2019 Reader's Choice Award Winner, 2019 Inc. 5000 list of the fastest-growing private company in America, Best Place to Work 2019, TMC 2018 Communications Solutions Products of the Year Award and many others.

Based on the questionnaires which given by Liu (2020) to the students to know the extent of the students' perception in implementing online course through zoom cloud meeting, there are $12,30 \%$ very agree with zoom cloud meeting course, 46,93\% agree, 25,28\% hesitant, 7,40\% disagree and 3,17\% very disagree with online learning course through zoom cloud meeting, (Liu \& Ilyas, 2020) from this preliminary, the researcher interested in analyzing the applying of zoom cloud meeting app towards EFL learning. Besides, the curiosity

\section{British, Jurnal Bahasa dan Sastra Inggris}


of the researcher to know the students' perspective, the barriers, the advantages and disadvantages of applying zoom cloud meeting app in pandemic era Covid-19 as well as the strategies to improve EFL learning by using Zoom Cloud Meeting App. The researcher also wants to conduct the research at STMIK Handayani Makassar. This campus located at jl. Adyaksa Baru No.1 Makassar, South Sulawesi, Indonesia. STMIK Handayani Makassar has responded the instruction of the government to apply online learning also similar with the other universities in Indonesia. Most of learning and teaching process use zoom cloud meeting app in this pandemic era Covid-19. This research becomes very essential to be observed right now because this pandemic is truly occurs in our daily life, both of lecturers and students already felt the condition of learning and teaching process in pandemic era. The issues of Covid-19 are a moment ago, so that the research regarding with this term is very rare. As the educators have to against this pandemic through using online learning, one of all applying Zoom cloud meeting app.

Based on the background as stated before, the researcher formulates some research questions are as follow:

(1) How is the students' perspective of applying Zoom Cloud Meeting app towards EFL learning of STMIK Handayani Makassar in Pandemic Era Covid-19?

(2) What are the barriers faced by the students of STMIK Handayani Makassar towards applying Zoom Cloud Meeting app in EFL learning?

(3) What are the advantages and disadvantages of applying Zoom Cloud Meeting towards EFL learning of STMIK Handayani Makassar students in Pandemic Era Covid-19?

(4) How are the strategies to improve EFL learning through applying Zoom Cloud Meeting of STMIK Handayani Makassar in Pandemic Era Covid19 ? 


\section{RESEARCH METHOD}

\section{Research Design}

The researcher employed descriptive qualitative design to analyze the phenomena so that able to answer the research questions of this research explicitly. The data of this research were analyzed by using words rather than number. It's suitable with the statement from (Sugiyono, 2010)states that qualitative research is descriptive; the data is in the form of words rather than number. It concerned with process, rather than simple outcomes or product, qualitative research tends to analyze the data inductively. Sugiyono also states that qualitative research is a research that used to describe and analyze phenomena, event, social, activity, attitude, belief, perception, and people thinking either in individual or in group.

\section{Research Subject}

The subject of this research is the students of STMIK Handayani Makassar comprise Manajemen Informatika (MI) Department and Teknik Informatika Extensive (TI extensive) Department. The researcher will choose 5 students from Manajemen Informatika (MI) and 5 students also from Teknik Informatika Extenxive (TI Ekstensive) Department randomly as a sample of this research.

\section{Research Instrument}

The researcher applied two instruments to answer the research questions of this research. The instruments are self-report questionnaire and interview.

\section{Self-Report}

Self-reports are derived from participants' free descriptions of their own feeling and personalities. I may request a focus on certain trait domains, or be as loose as possible with an instruction. The advantages of self-reports are efficient and inexpensive. It requires only the cooperation of the target person; in contrast, the collection of informant ratings, behavior assessment, or life data,(Robins et al., 1999).

\section{Interview}

Interviews are ways for participants to get involved and talk about their views. In addition, (Cohen et al., 2017) explains“... the interview is not simply

\section{British, Jurnal Bahasa dan Sastra Inggris}


concerned with collecting data about life: it is part of life, its human embeddedness is inescapable." According to (Gray, 2014) "There are many reasons to use interviews for collecting data and using it as a research instrument, such as: there is a need to attain highly personalized data, there are opportunities required for probing, a good return rate is important, and informants are not fluent in the native language of the country, or where they have difficulties with written language. In this research, the researcher applied semi-structured interviews of this research. The type of this interview is non-standardized and is frequently used in qualitative analysis. The interviewer does not do the research to test a specific hypothesis. I have a list of key themes, issues, and questions to be covered. In this type of interview the order of the questions can be changed depending on the direction of the interview. An interview guide is also used, but additional questions can be asked, (David \& Sutton, 2011)

\section{Procedure of Collecting Data}

The researcher gathered the data by using two instruments as stated above. The procedures of collecting the data are as follows:

\section{Self-Report Questionnaire}

a. The researcher distributed the self-report questionnaire paper to the participants.

b. The participant answered the essay question in the self-report questionnaire honestly regarding with the main point of this research to gather as much as possible data to answer the research questions.

c. The self-report questionnaires were analyzed by the researcher.

\section{Interview}

a. The researcher prepared some questions to the participants regarding with the focus of this research.

b. The researcher conducted semi structured interview with open ended questions to the participants by using voice recorder.

c. The participants answered the questions from the researcher honestly. 


\section{Data Analysis}

The researcher analyzed by collecting the data from the instruments, sel report questionnaire and interview. The procedures of analyzing the data are as follows:

Self-Report Questionnaire

1. The researcher typed the report from the participants.

2. The researcher translated into English and classify the self-report from the participant which suitable to answer the research questions.

Interview

1. The researcher transcribed the voice recorder from the participants

2. The researcher identified and classified the answer which appropriate with the answer of the research questions.

3. The researcher translated the classified transcriptions into English.

\section{RESEARCH FINDING AND DISCUSSION}

\section{A. The students' perspective of applying Zoom Cloud Meeting app towards EFL learning}

Most of people are running their classroom by applying zoom cloud meeting app. Learning teaching process notably EFL learning has to use this app to make the education keep existing in the world because of pandemic era Covid 19. The illustration about the students' perspective in applying zoom cloud meeting app in EFL classroom from both of instruments either in the self-report questionnaire or in the interview were represented in the table below:

Table1.The perspective of applying Zoom Cloud Meeting app towards EFL learning

\begin{tabular}{lccc}
\hline \multicolumn{1}{c}{ Informant } & Effective & Moderate & Not Effective \\
\hline $1^{\text {st }}$ informant & $\sqrt{ }$ & \\
\hline $2^{\text {nd }}$ informant & $\sqrt{ }$ & \\
\hline $3^{\text {rd }}$ informant & $\sqrt{ }$ & \\
\hline $4^{\text {th }}$ informant & $\sqrt{ }$ & \\
\hline $5^{\text {th }}$ informant & & & \\
\hline $6^{\text {th }}$ informant & & $\sqrt{ }$ \\
\hline $7^{\text {th }}$ informant & $\sqrt{ }$ & \\
\hline
\end{tabular}




\begin{tabular}{ll}
\hline $8^{\text {th }}$ informant & $\sqrt{ }$ \\
\hline $9^{\text {th }}$ informant & $\sqrt{ }$ \\
\hline $10^{\text {th }}$ informant & $\sqrt{ }$ \\
\hline
\end{tabular}

The discussion of the findings from both of instruments either in the selfreport questionnaires or interview given to the students revealed that there are seven informants have the perspective of applying zoom cloud meeting app in EFL learning are effective to stop the spreading of Covid 19 in pandemic era. Two informants of them say that moderate because they assume that indeed, the application of zoom cloud meeting is one of all way to face the pandemic era but it cannot be perfect to be applied in learning EFL because many obstacles faced by the students especially the network. Moreover the fifth informant says that this zoom cloud meeting is not effective because she doesn't understand the explanation of the lecturer through zoom cloud meeting. It cannot be denied that many kinds of perceptions from the informants regarding with the application of zoom cloud meeting in EFL classroom because every students has different style of learning, competence and desires. It's appropriate with (Mansor \& Ismail, 2012)said that different students have different learning styles that results in them having different perspective on online learning using ICT tools hence different commitment towards online learning. It referred to the findings below based on the self-report questionnaires and interview from the first informant (MI) and the sixth informant (TI Extensive):

The first informant says that this app is very exact and appropriate with the regulation of the government to stop the corona virus in pandemic era. It's similar with (Phillips, 2015)mentions in her article that "internet-based education was more likely to be accepted by students if they perceived that it offered an advantage over traditional alternatives, was technically easy to use, and was compatible with their values/norms". See his statement below:

a. From the self-report

Question : : How is your point of view about the use of Zoom Cloud Meeting app in learning teaching process to face Covid 19 in pandemic era? 
Answer : It's already very good. This step is a regulation from the government to tackle the spreading of corona virus

\section{b. From the interview}

From this interview, He said that by applying this app, it can minimize the spreading of corona virus in Indonesia and actually the lack is just a little in the learning teaching process because we can communicate each other. See his statement below:

Interviewer : How is your opinion or point of view about the use of Zoom Cloud Meeting app in learning English in Covid 19 pandemic era?

Informant : The first sir, this pandemic era is already very long in Indonesia and many ways were already conducted and we are not free from covid 19 until now, but we can minimalize by applying this step. Even in learning process, the lack is just a little. Because we are still can communicate, it's an exact step in this pandemic era.

Whereas the sixth informant assumed that indeed this app is one of all way to run the learning and teaching process but so many obstacles faced by him especially the network. Therefore, it cannot be perfect to be applied in EFL learning. It's similar with the findings of (Shukri et al., 2020)that students perceive online learning using ICT tools as beneficial. However, the students also believe that online synchronous learning is not as effective as traditional classes. See his statement below:

\section{a. From the self-report}

Question : How is your point of view about the use of Zoom Cloud Meeting app in learning teaching process to face Covid 19 in pandemic era?

Answer : The use of Zoom app in learning process in this pandemic era is one of all ways to run the learning process. However, according to me the learning process cannot be running perfectly because many obstacles such as the network especially. This online learning teaches us to be

b. From the interview lazy, because we can study even in the bedroom.

In the interview, the sixth informant statement is similar with the selfreport questionnaire but he emphasizes that this zoom app is effective

\section{British, Jurnal Bahasa dan Sastra Inggris}


enough to conduct an online learning even though many obstacles faced by them. See his statement below:

Interviewer : Okay Fatur, How is your point of view about the use of Zoom Cloud Meeting app in learning English in Covid 19 pandemic era?

Informant : In my point of view, the use of zoom cloud meeting is not perfect but this is an effective app to do an online learning sir in this situation. Even though there are many problems in online learning like this.

\section{B. The barriers faced by the students towards applying Zoom Cloud Meeting}

The barriers certainly always exist in our activity or life. It's same with the application an online learning app namely zoom cloud meeting. Even though, most of people assume that this is one of all effective program or app to continue the educational word in pandemic era of Covid 19. The researcher is sure that many barriers are faced by the users during applying this app as a learning medium. The data about the barriers of applying zoom cloud meeting from boyh of instruments are as follow:

Table 2.The barriers towards applying zoom cloud meeting in EFL learning

\begin{tabular}{ll}
\hline Informant & The barriers towards applying Zoom Cloud Meeting \\
\hline $1^{\text {st }}$ informant & The network and the budget \\
\hline $2^{\text {nd }}$ informant & The network \\
\hline $3^{\text {rd }}$ informant & The network and the quota consume \\
\hline $4^{\text {th }}$ informant & The network is not good \\
\hline $5^{\text {th }}$ informant & The network, the quota consume and many assignment \\
\hline $6^{\text {th }}$ informant & The network is low, miscommunication in learning \\
\hline $7^{\text {th }}$ informant & The network in the rural area \\
\hline $8^{\text {th }}$ informant & The network and the quota consume \\
\hline $9^{\text {th }}$ informant & It depends on the network \\
\hline $10^{\text {th }}$ informant & The quota consume \\
\hline
\end{tabular}

Based on the data gathered from the instruments, Most of informants complain about the network is not good especially in the rural area and the use of British, Jurnal Bahasa dan Sastra Inggris 
quota is big. In addition, the fifth informant said that by applying of zoom cloud meeting so many assignments given to her while the sixth informant states that miscommunication in learning become the barrier is usually faced by them. Besides, the first informant complains about the voice and the video are not clear because of the bad network and the usage of quota is increased. (Shukri et al., 2020)conclude their research that not all students are able to access the internet from where they are. Due to the weak internet connection, students may not be able pay attention to the lesson and, teaching and learning part becomes ineffective because of the challenges faced by the student. In order to achieve the full benefits of synchronous learning, the foundation needs to be established beforehand such as the internet connection, proper facilities, appropriate teaching materials, teachers' and students' readiness to implement synchronous learning. See his statement below:

\section{a. From the self-report}

Question : What are the obstacles while using Zoom Cloud Meeting app during Covid 19 pandemic era?

Answer : The main problem is while the internet network disrupted so that the voice and video are not clear. After that, expending

b. From the interview of quota increased

In the data of interview, the first informant says that the barriers are usually faced by him regarding with the technical such as a natural disruption and signal disruption while in the learning teaching process, he says that it depends on the students it selves. See his statement below:

Interviewer : Oh Haidar, what obstacles which were found during learning English through Zoom Cloud Meeting?

Informant : More to the technical sir

Interviewer : Yes, how is the technical?)

Informant : Such as natural disruption, especially for the learning process actually is not much disruption because we cannot meet face to face, maybe it depends on the students itself, if they want to learn the materials or just attend the meeting. It's like that sir

While the sixth informant said that the main obstacle is the low network especially the friends who live in the rural area. In addition, it's difficult to

\section{British, Jurnal Bahasa dan Sastra Inggris}


communicate with other friends or lecturer so that it effects on the delivering of material to the students. Have a look his statement below:

\section{a. From the self-report}

Question: What are the obstacles while using Zoom Cloud Meeting app during Covid 19 pandemic era?

Answer : The main obstacle is the slow network moreover for the friends who live in the rural area. Another obstacle is very difficult to communicate with the lecturer and friends so that it gives an impact to the imperfect delivering materials. Sometimes, the question and answer is not concord.)

\section{b. From the interview}

In the interview, the sixth informant also states the similar with his statement of the self-report questionnaire that the network and the communication are the barriers faced by him. See his statement below:

Interviewer : Oh yes, so what obstacles are found by Fatur while learning and teaching with Zoom Cloud Meeting app?

Informant : Usually the network is slow; it's the main problem sir while in the rural/ area sir)

Interviewer : So the main obstacle is the network. What else the obstacles?

Informant : Usually it's so difficult to communicate with the lecturer sir; it's because of the network sir. It's usually not fast and finally, we don't understand the explanation from the lecturer.

C. The advantages and disadvantages of applying Zoom Cloud Meeting in Pandemic Era Covid-19

In pandemic era of Covid 19 in Indonesia, most of academicians utilize an application namely zoom cloud meeting app to run the learning and teaching process in order to avoid and stop the spreading of corona virus. Certainly, the existence of this app gives the advantages and disadvantages during applying this app in learning and teaching process. The data gathered regarding with the advantages and disadvantages of zoom cloud meeting based on the instruments are revealed below.

Table 3. The advantages and disadvantages of applying Zoom Cloud Meeting

\begin{tabular}{ccc}
\hline Informant & Advantages & Disadvantages \\
\hline $1^{\text {st }}$ informant & Flexible, Health protocol can be kept, & Quota consume, Interaction is
\end{tabular}

\section{British, Jurnal Bahasa dan Sastra Inggris}




\begin{tabular}{|c|c|c|}
\hline & Comfortable & $\begin{array}{l}\text { not maximal, The learning } \\
\text { condition cannot be felt in the } \\
\text { classroom }\end{array}$ \\
\hline $2^{\text {nd }}$ informant & $\begin{array}{l}\text { Make the students easier and the } \\
\text { features of Zoom app is good }\end{array}$ & Quota consume \\
\hline $3^{\text {rd }}$ informant & $\begin{array}{l}\text { Can learn through online, Stand alone } \\
\text {, Avoid the crowded }\end{array}$ & $\begin{array}{l}\text { The network must be good } \\
\text { and the quota consume }\end{array}$ \\
\hline $4^{\text {th }}$ informant & $\begin{array}{l}\text { Many kinds of features and } \\
\text { the features are } \\
\text { good }\end{array}$ & $\begin{array}{l}\text { Less secure, the feature } \\
\text { is still using English, The quota } \\
\text { consume }\end{array}$ \\
\hline $5^{\text {th }}$ informant & Can live with the family in the village & $\begin{array}{l}\text { The quota consume and the } \\
\text { learning cannot be understood } \\
\text { well }\end{array}$ \\
\hline $6^{\text {th }}$ informant & $\begin{array}{l}\text { Can do two activities in a schedule, can be } \\
\text { relaxed }\end{array}$ & $\begin{array}{l}\text { The learning is not perfect, make } \\
\text { the students lazier, less of } \\
\text { togetherness }\end{array}$ \\
\hline $7^{\text {th }}$ informant & Can be working while studying & $\begin{array}{l}\text { Cannot meet the friends } \\
\text { directly in the classroom }\end{array}$ \\
\hline $8^{\text {th }}$ informant & $\begin{array}{l}\text { The big capacity, many kinds of features, } \\
\text { high quality access }\end{array}$ & $\begin{array}{l}\text { The quota consume and } \\
\text { the data is insecure }\end{array}$ \\
\hline $9^{\text {th }}$ informant & It's very helping in this pandemic era & When the network is not good \\
\hline $10^{\text {th }}$ informant & $\begin{array}{l}\text { It's very helping to stop the Covid } 19 \\
\text { in pandemic era }\end{array}$ & $\begin{array}{l}\text { Less of interaction with friends } \\
\text { and lecturer }\end{array}$ \\
\hline
\end{tabular}

The table above shows the advantages and disadvantages of applying zoom cloud meeting app toward EFL learning. Certainly, in an application or program has an advantage and disadvantage in applying that program. It's same with this app namely zoom cloud meeting has some advantages and disadvantages towards EFL learning. Regarding with the advantages of this app, there are three informants say that zoom cloud meeting has many kinds of good features and high quality access. Besides, there are four informants say that it's very helping to stop the spreading of Covid 19 in this pandemic era because the crowded can be avoided and the health protocol can be kept. In addition, some informants feel an easy of their live such as its more flexible, comfortable, stand alone and relaxed. Moreover, the informants can learn through online, can do two activities in a schedule, can be working while studying and can be stay at home with family. This is also supported by (Mansor \& Ismail, 2012)where both authors discussed about the advantages of blended synchronous learning. One of it is it is flexible and its

\section{British, Jurnal Bahasa dan Sastra Inggris}


flexibility offers students the accessibility on teaching materials and the lesson anytime, anywhere and in any way. It provides the students with the freedom to determine the way they want to study.

Concerning about the disadvantages of zoom cloud meting app, there are six informants complain with the usage of big quota, two informants say that the bad network, three informants also complain with less of interaction among friends and lecturers, less secure of data is stated by two informants. It's appropriate with (Phillips, 2015)said that online learning will be more effective if feedbacks are able to be communicated, thus, online learning becomes more interactive. Some informants are talking about the situation in the learning and teaching process such as the learning condition cannot be felt, the learning is not perfect, make the students lazier and less of togetherness. The findings of the table above based on the self-report questionnaires and interview. The findings were illustrated below from the first informant and the sixth informant:

The first informant said three advantages and three disadvantages also. The first informant can run the learning everywhere, health protocol can be kept and the learning can be adjusted with his comfort. Those are the advantages based on the first informants while the disadvantages of zoom cloud meeting the first informant says that the usage of big quota, the interaction is not maximal and the learning condition cannot be felt. See his statement below:

\section{a. From the self-report}

Question : According to you, what are the strength and the weakness in learning English by using Zoom Cloud Meeting in pandemic era?

Answer : The strength: The learning can be running everywhere, health protocol can be kept, and the comfortable learning can be adjusted. The weakness: the use of quota is big, interact in learning material is not maximal, the learning condition cannot be felt.

\section{b. From the interview}

Similar with in the self report questionnaire, the first informant also reemphasizes that the easy of live such as the comfortable learning can be adjusted and the disadvantages of zoom cloud meeting is the usage of big internet quota in learning teaching process. See his statement below:

\section{British, Jurnal Bahasa dan Sastra Inggris}


Interviewer: Yes right, in your mind, what are the strengths of this Zoom Cloud Meeting?

Informant : Personally sir, the first is we can adjust the comfort it's like this we can study at home such as outdoor place. The second is not difficult sir, for instance we have to prepare something if we want to go to the campus, traffic jam in the road to the campus, the weather such as rain or so far from campus. It's not influenced if we use Zoom sir)

Interviewer: Oh Yes, how about the weakness Haidar, according to you?

Informant : The first weakness sir, and maybe most of us answer the quota sir, the expending of quota is very big. It's not only the students but also all of people use zoom)

While the sixth informant says that the advantages of zoom cloud meeting are two activities in a schedule can be done and the learning process can be relaxed while the disadvantages are regarding with the situation of the learning teaching process as usual in the classroom. Have a look his statement below:

\section{a. From the self-report}

Question : According to you, what are the strength and the weakness in learning English by using Zoom Cloud Meeting in pandemic era?

Answer : The strength: We can follow two activities in a schedule and the learning process is relaxed. The weakness: The learning is not perfect, the students can be lazy, cannot get acquaintance each other, and the togetherness among friends are not created.

\section{b. From the interview}

In the interview some of his statements in the self-report questionnaire are repeated. See his statement below:

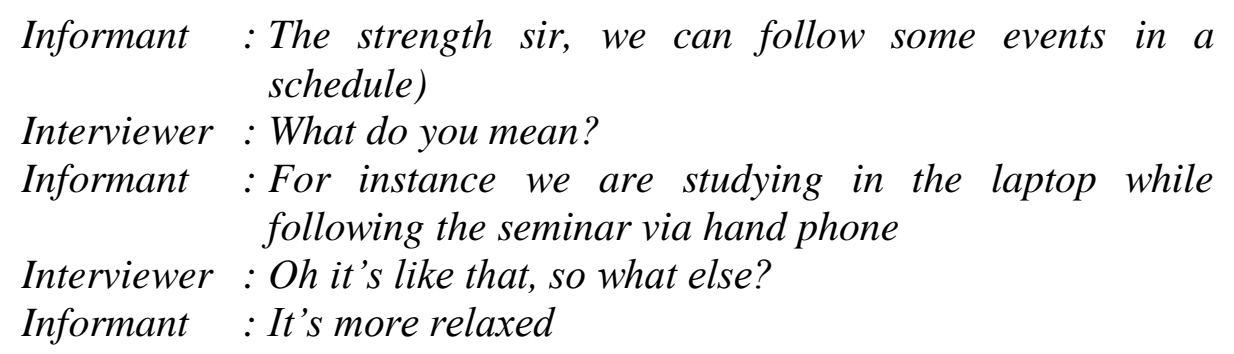

\section{The strategies to improve EFL learning through applying Zoom Cloud}

\section{Meeting}

Applying an application as a medium in learning EFL is not like learning and teaching process conventionally. Even though both of them need an effective

\section{British, Jurnal Bahasa dan Sastra Inggris}


strategy but by using a technology needs more effective and efficient strategy based on the students' comfort and desires. The effective strategies based on the students perspective from the self-report questionnaire and the interview are illustrated below.

Table 4. The strategies to improve EFL learning through applying Zoom Cloud Meeting

\begin{tabular}{ll}
\hline Informant & The strategies to improve EFL learning \\
\hline $1^{\text {st }}$ informant & $\begin{array}{l}\text { The evaluation and the pronunciation practice are added, The video } \\
\text { must be on, the activity is individual }\end{array}$ \\
\hline $2^{\text {nd }}$ informant & Help the students a quota in learning \\
\hline $3^{\text {rd }}$ informant & Help the students a quota to learn eminently \\
\hline $4^{\text {th }}$ informant & The students must be more motivated \\
\hline $5^{\text {th }}$ informant & The time management, the lecturer must be focused and consistent \\
\hline $6^{\text {th }}$ informant & Form the small group learning to discuss the material \\
\hline $7^{\text {th }}$ informant & $\begin{array}{l}\text { The informant doesn't know the effective strategies to improve EFL } \\
\text { learning }\end{array}$ \\
\hline $8^{\text {th }}$ informant & The method must be interactive \\
\hline $9^{\text {th }}$ informant & The materials have to be delivered directly with audio and visual \\
\hline $10^{\text {th }}$ informant & Do an offline learning once or twice in the campus \\
\hline
\end{tabular}

There are nine informants suggest the strategies to improve EFL learning by using zoom cloud meeting in this pandemic era and one informant else doesn't know how the good strategies to improve EFL learning by using zoom app. The findings of the data based on the self-report questionnaires and interview from the first informant and the sixth informant were illustrated as follow:

The first informant based on the self-report said that the evaluation about the materials can be added, pronunciation practice and disciplinary can be increased. See his statement below:

\section{a. The data from self-report}

Question : According to you, how is the effective strategy to improve the English learning through Zoom Cloud Meeting during Covid 19 pandemic era? 
Answer : The evaluations about the materials to the students can be added in order that the learning can be more active. The pronunciation practice can be added, it's necessary to increase the disciplinary to follow the learning such as the video must be on, the activity is more individual than group.

\section{b. The data from interview}

In the interview the first informant suggests to increase the interaction with the students and decrease the theory. See his statement in the interview below:

Interviewer: Oh yes, the last one according to you how is the effective strategy through zoom cloud meeting?

Informant : According to me personally sir, it's better to decrease the theory and increase the interaction in learning, for instance the students appoint directly so that the students are not relaxed in learning

Based on the self-report questionnaire and interview, the sixth informant suggests forming a small group discussion to share or discuss something together but keep obeying the available health protocol. See his statement below:

\section{a. From the self-report}

Question : According to you, how is the effective strategy to improve the English learning through Zoom Cloud Meeting during Covid 19 in pandemic era?

Answer : According to me the effective way is by forming a small group to learn together so that we can share and discuss each other. The learning schedule can be arranged with a small group and stay obeying the available health protocol

\section{b. From the interview}

In the interview, the sixth informant also states similar with the self-report questionnaire to form a small group discussion in learning EFL. Have a look his statement below:

Interviewer : Okay, How about you the effective strategy in teaching through Zoom Clou Meeting?

Informant : In order to the learning can be effective, maybe we can form a small group. I mean we have a friend to share and discuss in learning.

Interviewer : Oh need a friend to discuss?

Informant : Yes sir

Interviewer : Okay, what else?

Informant : Maybe just that sir

\section{British, Jurnal Bahasa dan Sastra Inggris}


Based on theinformants of this research regarding with the strategies to improve EFL learning by using Zoom Cloud Meeting app. The informants assumed that the lecturer has to manage the process of EFL learning by using this app such as the lecturer must be focused and consistent, pay attention with the time management, the learning activity should be individual and well-arranged, the method must be interactive, the materials have to be delivered by using audio and visual and the most important thing by using zoom app is the video of the students must be active. Besides, the informants also need big internet quota to follow the learning and teaching process and need to be motivated more.

\section{CONCLUSION}

This research is an endeavor to analyze of applying zoom cloud meeting app toward EFL learning in pandemic era Covid 19. Based on the findings and discussion in the previous one, the researcher put forward the following conclusions based on the self-report questionnaire and interview:

Many kinds of perspectives of the informants regarding with applying zoom cloud meeting in pandemic era covid 19. There are seventh informants said that the application of zoom cloud meeting in EFL learning are effective, two of them are moderate and just an informant who says not effective. The researcher concludes that the existence of zoom cloud meeting in EFL learning are very effective to stop the spreading of covid 19 in pandemic era but the learning process cannot be perfect than the conventional learning.

There are many barriers toward applying zoom cloud meeting in EFL learning. Most of informants say that the network and the big usage of quota are the barriers of applying the app in EFL learning. In addition, the informants complain many assignments and miscommunication in learning. The researcher concludes that the main barriers of applying zoom cloud meeting are the bad network and the usage of big quota.

The advantages of applying zoom cloud meeting in EFL learning are many kinds of good features and high quality access, more flexible, comfortable, stand alone and relaxed. Besides, it's very helping to stop the spreading of Covid 19 in this pandemic era because the crowded can be avoided and the health protocol can 
be kept. In addition the informants can learn through online, can do two activities in a schedule, can be working while studying and can be stay at home with family. Whereas the disadvantages of zoom cloud meeting are the situation in the learning and teaching process such as the learning condition cannot be felt, the learning is not perfect, make the students lazier and less of togetherness. Moreover, the usage of big quota, the bad network, less of interaction among friends and lecturers, and less secure of data.

The strategies to improve EFL learning through zoom cloud meeting are helping the students a quota to learn eminently, forming the small group learning to discuss the material, doing an offline learning once or twice in the campus. In addition, the evaluation and the pronunciation practice are added, The video must be on, the activity is individual, the method must be interactive, the materials have to be delivered directly with audio and visual, The time management, the lecturer must be focused and consistent and the students must be more motivated.

\section{REFERENCES}

Atmojo, A. E. P., \& Nugroho, A. (2020). EFL Classes Must Go Online! Teaching Activities and Challenges during COVID-19 Pandemic in Indonesia. Register Journal. https://doi.org/10.18326/rgt.v13i1.49-76

Cohen, L., Manion, L., \& Morrison, K. (2017). Research Methods in Education. In Research Methods in Education. https://doi.org/10.4324/9781315456539

David, M., \& Sutton, C. (2011). Social Research: An Introduction. In Getting Started: Theory, Research Question and Research Design.

Gray, D. E. (2014). Doing Research in the Real World (3rd ed.). In SAGE.

Jacobs, P. (2013). The challenges of online courses for the instructor. Research in Higher Education Journal.

Liu, A. N. A. M., \& Ilyas, I. (2020). Pengaruh Pembelajaran Online Berbasis Zoom Cloud Meeting Terhadap Hasil Belajar Mahasiswa Fisika Universitas Flores. Jurnal Pendidikan Fisika Dan Keilmuan (JPFK). https://doi.org/10.25273/jpfk.v6i1.7303

Mansor, M. S. A., \& Ismail, A. (2012). Learning Styles and Perception of Engineering Students Towards Online Learning. Procedia - Social and Behavioral Sciences. https://doi.org/10.1016/j.sbspro.2012.11.459

Phillips, J. A. (2015). Replacing traditional live lectures with online learning

\section{British, Jurnal Bahasa dan Sastra Inggris}


modules: Effects on learning and student perceptions. Currents in Pharmacy Teaching and Learning. https://doi.org/10.1016/j.cptl.2015.08.009

Robins, R. W., Norem, J. K., \& Cheek, J. . (1999). Naturalizing the Self. Handbook of Personality: Theory and Research.

Shukri, A., Nordin, L., Salleh, F. I. M., Raidzwan, S. N. M., \& Ahmad, R. (2020). UniKL students' perception on synchronous learning using ICT as learning tools to learn english. Journal of Critical Reviews. https://doi.org/10.31838/jcr.07.08.170

Sugiyono, P. D. (2010). Metode Penelitian Bisnis. Pendekatan Kuantitatif, kualitatif dan R \& D. In Bandung: Alfabeta.

WHO. (2020). COVID-19 COVID-19. WHO Journal for Covid 19, Region Situational Update for the Africa.

Yulia, H. (2020). Online Learning to Prevent the Spread of Pandemic Corona Virus in Indonesia. ETERNAL (English Teaching Journal). https://doi.org/10.26877/eternal.v11i1.6068 